\title{
PINOCYTOSIS IN THE DEVELOPING EGG OF LIMNAEA STAGNALIS L.
}

\author{
P. F. ELBERS and J. G. B LUEM I N K \\ Centrum voor submicroscopisch onderzoek van biologische objecten and Zoologisch Laboratorium, \\ Rijksuniversiteit, Utrecht, Holland
}

Received October 22,1960

$I_{N} 1946$ Raven [13], working with sections of Limnaea eggs, described numerous vacuoles appearing in the ectoplasm at the 40 cell stage. Their content was strongly eosinophilic and with all stains used the colour of the vacuole content corresponded to that of the egg capsule fluid surrounding the egg.

During the development of the egg the albumen vacuoles became larger and larger, occupying at the 120 cell stage a large part of the ectoplasm.

Also at the 40 cell stage small conical or hemispherical vesicular protrusions could be observed on the surface of some blastomeres. Others had the appearance of small thickened rings of variable diameter, protruding slightly above the surface of the cells and surrounding a crater-like field.

At the 120 cell stage their number had increased considerably and $40-60$ of such ringlets were observed in most eggs.

Since the formation of the ringlets corresponds in time to the absorption of albumen by the cells, Raven put forward the hypothesis that they represent inlets destined for the ingestion of egg capsule fluid by the developing egg. In order to test this hypothesis it seemed worthwile to study these structures by electron microscopy.

Malerials and methods.-Limnaea eggs were fixed at the 120 cell stage in 1 per cent osmium tetroxide buffered to $\mathrm{pH} 8$ with veronal acetate, with the addition of sucrose and $\mathrm{CaCl}_{2}$ [6]. After fixation the eggs were treated with 1 per cent phospho-tungstic acid in 70 per cent alcohol, dehydrated and embedded in bulyl-methacrylate. Sections were cut with the Porter-Blum microtome and with the microtome designed
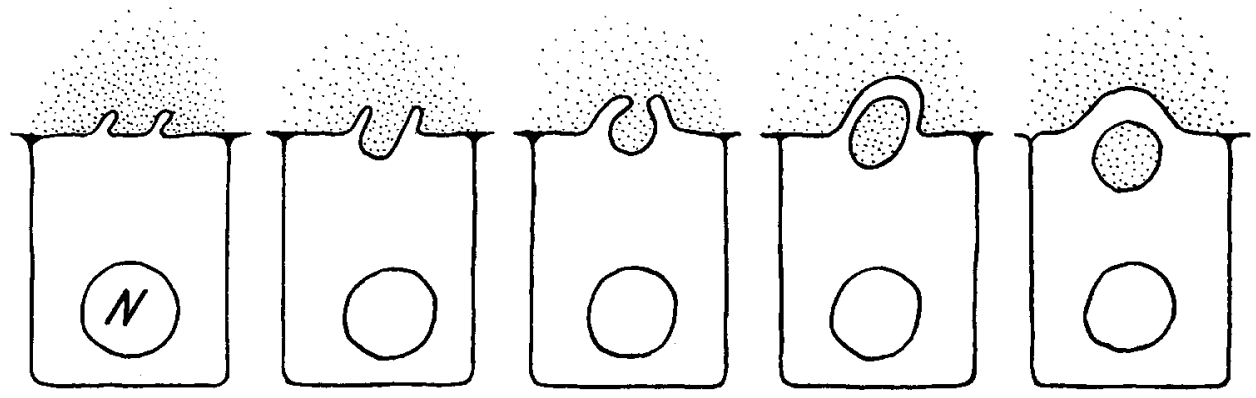

Fig. 1.-Stages of pinocytosis in Limnaea stagnalis blastula, schematic. $N$, nucleus. 
by Elbers [6]. In accordance with criteria described by Peachy [12] the thickness of sections used in this work was estimated to be about $600 \AA$.

Results.-The micrographs show protrusions at the cell surface with a diameter of from 2 to $4 \mu$. All stages between open and completely closed structures were seen. In all cases the completely closed structures show a vacuole surrounded by a double membrane with the dimensions of the cell membrane. The vacuoles have a diameter of from 1 to $2 \mu$. The contents of the vacuoles in the surface structures have a granular appearance. Arranging the different stages of the surface structures in a sequence we may construct the diagram of Fig. 1.

In the interior of the cell we also see vacuoles surrounded by a double membrane. Several of these vacuoles do not differ from the vacuoles lying in the closed structures at the surface of the cell, others show a slight difference inasmuch as they contain filamentous and electron-dense particles. The particles are irregularly spread and/or arranged in regular rows. They agree in size with the particles arranged in a crystalline pattern in the yolk granules as described by Elbers $[5,6]$. In several cases the membrane of these vacuoles was interrupted and its frec ends coiled up to the inside.

On sections of young gastrulae we observed similar structures at the surface of the entoderm cells, projecting into the gastrocoel.

Discussion.-The state of our knowledge on pinocytosis has been reviewed by Holter [8]. In the present paper the possible structural basis of a process of uptake of surrounding capsule fluid by developing eggs of Limnaea stagnalis has been described. This process shows all the features of pinocytosis. The ingestion of fluid by pinocytosis has generally been described as starting with invagination of the cell membrane, which forms a tunnel into the cell interior at the end of which small vacuoles are pinched off.

In Limnaea eggs the process starts with a ring-shaped elevation of the cell membrane. The ring wall becomes higher and higher, whereas generally the crater deepens and finally becomes closed. The vacuole so formed migrates into the cell interior.

The average diameter of the primary vacuoles is from 1 to $2 \mu$. The form of the ring structure is much like the one described by Chapman-Andresen and Prescott [4] in Amoeba proteus after ingestion of ciliates or methionine solution and the one described by Guttes and Guttes in the myxomycete Physarum polycephalum [7].

In amoebae, leukocytes and tissue cells the process can be initiated at will by the addition of certain substances to the medium as described by Chapman-Andresen [2, 3], Brandt [1], Schumaker [15], Holter and Holtzer [10], and Holter [9].

In the Limnaea egg the case is quite different. During its whole development the egg is surrounded by the egg capsule fluid and only during a distinct period in this development does pinocytosis occur. This may be induced by the disruption of the vitelline membrane, which brings the cell surface into contact with the surrounding capsule fluid. It is not precisely known when the vitelline membrane comes off but it happens about two days after the first cleavage, before gastrulation. In this period pinocytosis takes place.

The composition of the capsule fluid of Limnaea eggs has been studied by Horstmann [11]. It contains about 15 per cent dry matter, 3-6 per cent of which is galactogen. The protein conlent is $6-8$ per cent (Geilenkirchen, personal communication). Thus high molecular substances are taken up by the Limnaea egg in the process of pinocytosis. 


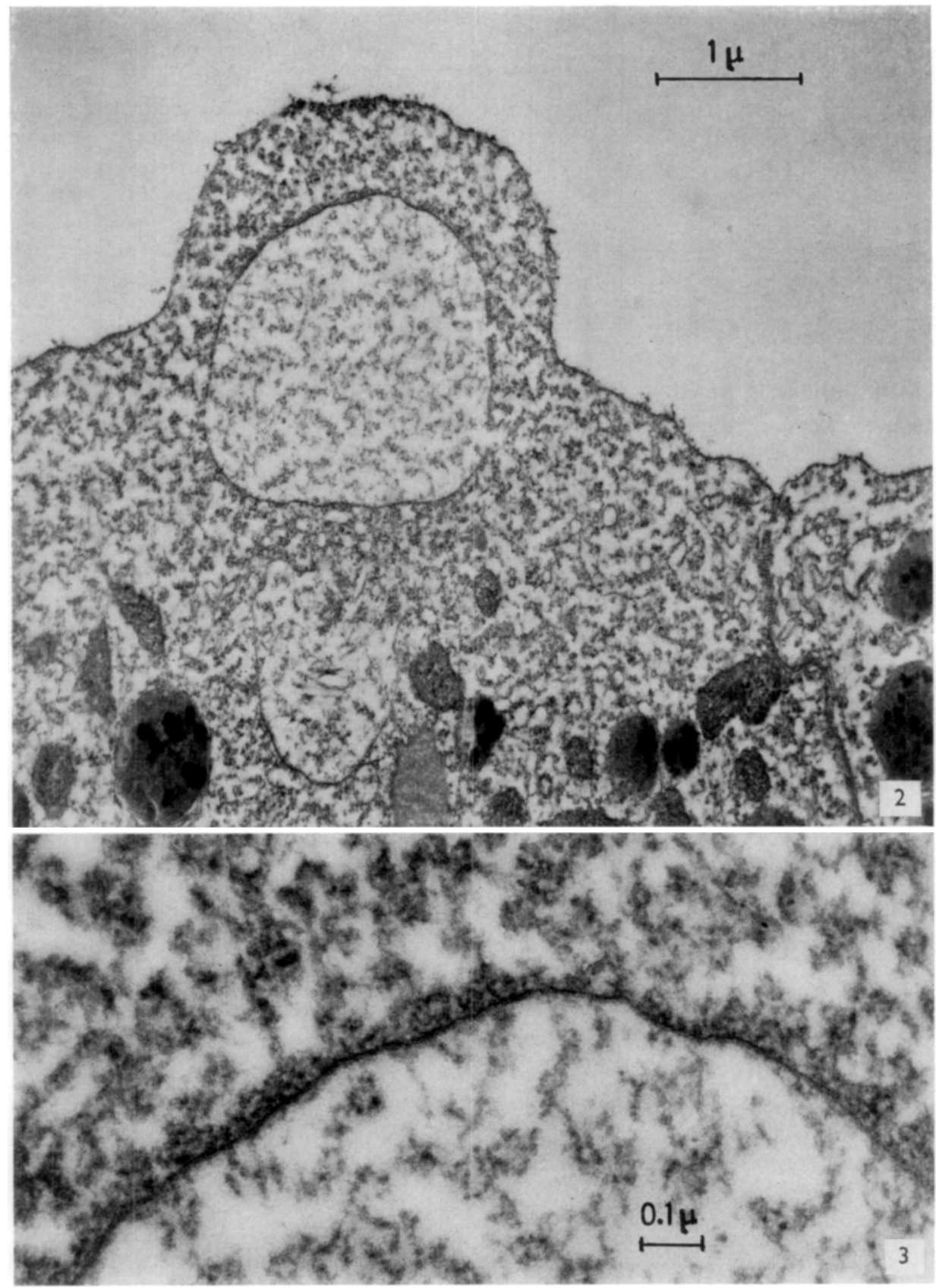

Fig. 2.-Completely closed protrusion with pinocytosis vacuole in Limnaea stagnalis blastula. Magnification $\times 20,000$.

Fig. 3.-Detail of Fig. 2. Vacuole membrane with a double structure like the cell membrane. Magnification $\times 80,000$.

The photographs have been taken with the Siemens Elmiskop I at $60 \mathrm{kV}$. 
The question of how these substances are released into the cell is a crucial problem, as stated already by Holter [9]. It has been supposed that the vacuolar membrane is digested by cytoplasmic enzymes so that the contents of the vacuoles may be releascd into the cytoplasm. On this point we may have found some evidence in the form of the interrupted and coiled-up vacuole membranes mentioned before. However, the study of the fate of the pinocytosis vacuoles in the interior of the cell is hindered by the circumstance that at the same time vacuoles of F $\gamma$-granules [14] are found, showing about the same size and appearance [5].

In order to overcome this difficulty, it is necessary to get the pinocytosis vacuoles tagged for electron microscopy. These tagged vacuoles in Limnaea eggs should offer a good opportunity to study the uptake of their contents by the cell. Investigations in this direction are being continued.

The authors are indebted to Prof. Raven for proposing this investigation.

\title{
REFERENCES
}

1. Brandt, P. W., Exptl. Cell Research 15, 300 (1958).

2. Chapman-Andrasfi, C., Exptl. Cell Research 12, 397 (1957).

3. —— Compt. rend. trav. Lab. Carlsberg Sér. chim. 31, 77 (1958).

4. Chapman-Andresen, C. and Prescot't, D. M., ibid. 30, 57 (1956).

5. Elbers, P. F., Proc. Koninkl. Ned. Akad. Wetenschap. 60, 96 (1957).

6. Thesis. Ltrecht (1959).

7. Guttes, E. and LutTes, S., Exptl. Cell Research 20, 239 (1960).

8. Holter, H., Intern. Rev. Cytol. 8, 481 (1959).

9. - - Ann. N.Y. Acad. Sci. 78, 2 (1959).

10. Holter, H. and Holtzer, H., Exptl. Cell Research 18, 421 (1959).

11. Hortsmann, H. J., Biochem. Z. 328, 342 (1956).

12. Peachy, L. D., J. Biophys. Biochem. Cytol. 4, 233 (1958).

13. Raven, Chr. P., Arch. Neёrl. Zoöl. 7, 368 (1946).

14. — - Morphogenesis: The Analysis of Molluscan Development, London, 1958.

15. Schumaker, V. N., Exptl. Cell Research 15, 314 (1958).

\section{ULTRASTRUCTURE OF SEGRETORY GRANULES IN POST- OVULATORY RABBIT OVIDUCT}

\author{
O. NILSSON and U. RUTBERG \\ Department of Histology and Department of Anatomy, Karolinska Institutet, \\ Stockholm, Sweden
}

Received October 25, 1960

THe secretory activity of the oviduct in the rabbit is influenced by ovarian hormones. In the oestrous stage, the secretory cells become charged with granules, which are excreted during the post-ovulatory phase [3 and others]. The granules of œstrous 